\title{
Application of Multicultural Music in Music Education in Colleges and Universities
}

\author{
Yi Ji \\ School of Music and Dance \\ Qujing Normal University \\ Qujing, Yunnan, China 655011
}

\begin{abstract}
With prosperity and development of social economy and education, the exchanges between nationalities and countries are more and more frequent. Cultural industry swarms into our country in succession. Music of different elements gathers and produces new sparks of art. It makes traditional, single and old music education changes as well. At present, multicultural music teaching idea has enjoyed more and more popular support of people and become the focus of time. In our country, the key point that we shall pay attention to at present is how to freely apply multicultural music education in college education.
\end{abstract}

Keywords-multicultural; music; music education in colleges and universities

\section{INTRODUCTION}

Since the reform and opening up, the educational pattern in our country adheres to single and traditional teaching model. Music education is not an exception. But meanwhile, in western countries, multicultural music education theory is gradually accepted by the public and becomes the main form and an indivisible part of western music education. With fast development of our country, various countries communicate with each other. All kinds of cultural exchanges collide. Western multicultural music education is introduced in China. Traditional music education mode has far from meeting demands of the times. Therefore, a kind of new educational method, multicultural music education mode, rises in response to the proper time and conditions and promotes the development of music teaching. It not only enhances students' artistic appreciation, but also provides nutrients for cultural exchanges between nationalities.

\section{NECESSITY AND INEVITABILITY TO IMPLEMENT Multicultural Music Teaching Method in Colleges}

Music education is an indispensable part of qualityoriented education in colleges. Music teaching is a very important part in quality-oriented education in colleges. It lays the foundation for students' comprehensive quality, ideology, value system and humanistic feelings. Music teachers in colleges shall determine teaching objectives, think about how to teach profoundly in teaching and explore how to carry out diversified music education. It is essential for teachers to devote themselves to it to promote the development of music education in colleges and cultivate more excellent professional talents for our country and the society. The implementation of multiplex teaching needs to respect diversification of culture, start from carrying forward music culture of our nation, learn, refer to and reflect other foreign music cultures, especially do in-depth research on cultural connotation under a variety of multicultural music. Only by doing this can they better improve students' musical talent.

When colleges implement multicultural music teaching, they can guide students to learn various kinds of music, understand music connotation of different nationalities, expand students' thinking and improve insights, and help students to cultivate their music personality and multiple musical sensibility under collision of multicultural music. Meanwhile, in the era of knowledge economy, when colleges implement multicultural teaching model, they shall also conform to the trend of international development and demand for development of times. This opportunity is mainly summarized as the following several points.

\section{A. National Education Is More and More Democratic}

Since the reform and opening up in our country, college education breaks through the past single and traditional teaching model and thinking model and tends to be more and more world-wide. Foreign democratic ideas are introduced to China accordingly, which improve the democratic ideas of people in our country. Colleges also begin to continuously pursue breakthrough and innovation and keep pace with the times. Under this tendency, college students also gradually begin to pursue their interest and knowledge and further study and research by centering on it. This macro factor urges music teaching model in our country to increasingly tends to multiculture and allow students to learn and further study according to their interest. This change greatly improves students' selfregulation of learning.

\section{B. New Generation of Talents with Multicultural Teaching Idea Springs up}

In our country, multicultural music teaching model can be traced back to the end of the 20th century at the earliest. After experiencing more than 20 years, music teachers who have multicultural concept have emerged in large numbers. In the development of music education, these teachers accept ablution of multi-culture. Diversified multicultural teaching mode has more profound understanding. Besides, just under 
the guidance of these teachers, subsequent students gain more knowledge under multicultural teaching mode to improve their learning quality.

\section{Cultural Globalization}

Since our country joins in WTO, economy and culture act on international convention. The degree of opening to the outside world is increasingly large. There are more and more opportunities for the culture of our country to exchange and communicate with foreign imported culture. Therefore, traditional and single teaching model in colleges changes slowly after injection of a large number of new blood, so that at present, teaching resources in colleges of our country have gained a qualitative leap and become colorful. Furthermore, with the advent of information age, internet development becomes more and more advanced and provides shortcut and convenience for multiplex teaching of music. Students can understand different cultural music through the internet, instead of being confined to learning of knowledge on textbook.

\section{DEVELOPMENT STATUS AND DEFICIENCIES OF Multicultural Music Teaching Method in Colleges}

Although the multicultural music teaching model in colleges of our country develops and grows vigorously, it has achieved a series of good results. But we shall also calm down and pay attention to some problems accumulated in the development process. It shows as follows.

\section{A. Music Education in Colleges of Our Country Is Excessively Single}

Although now music teachers in colleges carry out multicultural education in course, they pay more attention to teaching basic knowledge of music for students and tirelessly train students' musical skills. They seldom guide students to analyze inherent meaning of music, nor attach importance to cultivating students' aesthetic consciousness, let alone teaching through integrating music accomplishment with other humanities. In practical teaching, the teaching methods that college teachers teach music course have no obvious differences from other subjects. They all pay attention to theory inculcation. Besides, music teaching becomes elective course of students in other majors and it will not influence their marks. So students have no high enthusiasm to participate in it.

\section{B. Lack of Multicultural Education Concept in Colleges}

In music teaching of colleges in our country, traditional single teaching model always holds dominant position and makes ways and means of music teaching in the state of to be improved for a long time. It has direct influence on teaching contents and ways of teachers, as well as the overall status of school in the teaching of this professional field. For college teachers, compared with multicultural music teaching idea at the present stage, it is still impossible for them to keep pace with it. Thus it directly leads to the fact that when teaching, no matter on the concept or method, they stay on the traditional single music teaching system and cannot implement more skillful and professional teaching on professional knowledge, nor let students learn knowledge outside the traditional model. This kind of teaching model seriously impedes the improvement of overall quality of teaching staff in colleges.

\section{Colleges Lack Curriculum Provision of Multi-Culture}

If colleges want to carry out normal multicultural music education, they must build corresponding music course to pursue quantification of course as well as pursue reasonable course arrangement. While domestic colleges pay inadequate attention to curriculum provision of students. Besides, when most colleges carry out teaching work for students, because the teaching contents become numerous and complicated, the promotion of multicultural music teaching course in regular institutions of higher learning is restricted to some extent. The teaching ways and methods used by some college teachers in teaching process of multi-culture pay excessive attention to explanation of music skills and cannot realize deficiencies of multicultural music course in teaching. It leads to the fact that multicultural music teaching faces many difficulties in practice. Under this environment, under the premise of considering arrangement of other courses, it is very difficult for colleges to provide more teaching arrangement for course of multicultural music teaching. If things continue this way, it intensifies problems of multicultural music teaching appeared in implementation of course, and then forms vicious circle.

\section{Colleges Have Not In-depth Understanding for Contents of Multicultural Music Teaching}

With the development of economic globalization, cultural communication is more and more frequent. Multicultural music teaching methods and teaching contents also enrich and improve gradually. There are more and more learning resources for teachers and students in colleges to use. It is the problem demanding prompt solution about how to filtrate, choose and use plenty of resources. In content of music learning, college teachers still stay in the initial stage of multicultural teaching without in-depth understanding and research. Meanwhile, the deep understanding of various colleges on particularity of multicultural teaching objectives and multicultural music teaching shall be not embodied on technology and skills. It shall pay more attention to in-depth understanding of multicultural contents. Investigation shows that most students attach no importance to multicultural music teaching course carried out in colleges. In class, students are absent-minded. They cannot review and consolidate new knowledge after class. These aspects also seriously influence the effects of multicultural music teaching.

\section{E. Teaching Force Related to Multi-culture in Colleges Is Poor}

Although with the development of the times, multicultural music teaching in our country develops continuously. Many teachers with diversified musical talent spring up. The diversified music culture consciousness of them provides the impetus for promotion of multicultural music teaching. But these teachers account for a small proportion in the total number of music teachers. Although many multicultural music courses are carried out in colleges and have big scale, when 
teachers teach these diversified music culture, the knowledge taught by them are not very pure and professional. The thoughts expressed by them are relatively backward. It leads to the facts that they make mistakes in teaching courses, and the teaching contents and teaching methods are disordered. Furthermore, for a small part of multicultural music teachers, their ability and experience are limited. It is impossible for them to compare with traditional authentic multicultural music teaching methods. They can only teach part of knowledge for students to the utmost of their capacity.

\section{IMPLEMENT MEASURES OF MULTICULTURAL TEACHING METHODS IN COLLEGES}

\section{A. Build Multicultural Music Course System}

The development of multicultural music teaching in colleges has a close relationship with music course system. Course arrangement is the embodiment of teaching thought in college as well as the standard to measure teachers' teaching ability. In order to build multicultural music course system, it is necessary to pay adequate attention to the teaching of basic courses, such as music historical theory course, music theory course and music appreciation course. This is the basis for students to learn music. Only by laying a solid foundation can they faster accept further learning of music knowledge. In the process of building multicultural music course system, they shall reasonably arrange time for teachers to teaching music courses. Teachers shall coordinate time with each other. Reasonably arrange course and pay attention to arrangement of multicultural music course under the premise of ensuring rationalization of course system. If the courses drafted by school are inadequate, colleges shall firstly develop relatively important lessons and reinforce students' learning for selfstudy courses after class, and then guarantee completeness of courses.

\section{B. Enhance Professional Quality of Music Teachers in Colleges}

The professional quality of music teachers has a very important influence on music teaching. Colleges shall implement multicultural music teaching. The first requirement is that teachers have ability and connotation of multiplex teaching and they are loyal enough to diversified music teaching idea. In practical teaching, music teachers shall firstly have firm basic theoretical knowledge and be good at applying and innovating in music teaching methods, gradually guide students to actively exert subjective initiative and find learning interest in learning process. However, the responsibilities of college teachers are not limited to guiding students to study independently. What's more, they shall stimulate students' impetus, let students carry out professional innovation through their subjective initiative, base on their learning characteristics to find new learning methods to learn and innovate; then give comprehensive evaluation according to students' performance to stimulate students' interest in learning music. Under normal circumstances, colleges formulate training program for music education. On one hand, they want to cultivate students' learning ability and musical ability; on the other hand, they pay more attention to the inheritance of Chinese music culture and students' comprehensive quality such as independent consciousness, aesthetic idea and thinking value. Only by continuously improving students' comprehensive quality in music, broadening their horizon and thinking, integrating cultural characteristics of national music and creating works with more artistic value can they move towards palace of art of life.

\section{Strengthen Exchange of Music Culture in Colleges}

Traditional college education only pays attention to explanation and learning and ignores communication. In this kind of learning, students will feel very boring. After all, in the present college teaching, even the way of multicultural music teaching cannot achieve good results. Therefore, in multicultural music teaching in colleges, it is necessary to pay attention to communication between music cultures. They can invite well-known senior musicians outside school to explain and share experience with students, promote communication between students, then let students learn more knowledge about music in communication between students and students, students and teachers, students and musicians, and set a good example and value orientation of music for students. Furthermore, they can enhance students' professional quality. Meanwhile, college teachers shall continuously stimulate more students to participate in the practical activities to communicate, in order to deepen the understanding and experience for music.

\section{Promote Multicultural Teaching Idea of College Teachers}

As multicultural music teachers, it is the necessary condition to have multicultural music ability. Therefore, colleges shall pay attention to cultivating multicultural interactive consciousness and multicultural competence of college teachers. As college teachers, in order to find more teaching methods and smoothly carry out teaching activities, they can actively change educational concept and frequently popularize diversified music culture for students in practical teaching activities. At the same time, when college teachers carry out activities related to multicultural music teaching, if they can explain through consciously combining cultural characteristics of various regions and let students know more about multi-culture in the world, it will help to improve students' enthusiasm, stimulate their learning interest and integrate with theoretical knowledge to deepen the impression and carry out systematic learning.

\section{E. Reasonable Selection and Use of Excellent Teaching Resources}

In the era of information explosion, there are increasingly more and disordered resources to provide for multicultural music teaching. Therefore, college teachers and students shall learn to find useful and excellent teaching resources in the huge information and realize high quality of teaching resources, which help to improve the implementation of multicultural music teaching course and enhance efficiency. The successful implementation of teaching is closely linked with teaching resources. Teaching resource is a knowledge carrier for college teachers to acquire information resources in teaching process. Therefore, they shall be careful to choose teaching resources. 
For selection of textbook, college teachers shall firstly refer to representative foreign music for students as learning materials to ensure the music is pure and authentic.

\section{F. Improve Teaching Ability of Young Teachers in Colleges and the Change of Teaching Important Points}

Although a small number of music teachers in colleges have certain understanding for multicultural music teaching concept and model, their real teaching ability is remained to be improved. Therefore, colleges shall pay attention to cultivating teachers' practical experience for multicultural music teaching model and organize relevant training. Besides, for teachers with old-fashioned conception of thinking in schools, it is necessary to implement training of multicultural music teaching, in order to let these teachers adapt to multicultural music teaching model.

\section{CONCLUSION}

In multicultural music teaching, colleges shall base on local culture, integrate music culture in all regions, take the essence and discard the dregs, establish multicultural music teaching idea, build appropriate and reasonable education courses, improve and enrich their teaching staff, respect different custom and culture of all nationalities and learn to respect culture in different countries and nationalities, and strengthen exchanges between cultures.

\section{REFERENCES}

[1] Yan Hong. Analysis on Multicultural Music Education in China under the Perspective of International Society of Music Education [D], Heilongjiang, Harbin Normal University, 2012.

[2] Guan Jianhua. Education of Musicians on Horizon of Multicultural Education [J], Journal of Nanjing Arts Institute (Music and Performance), 2011 (03).

[3] Liu Guizhen. Time Strategy of Multicultural Music Education Development in Our Country $[\mathrm{J}]$, Journal of Northeast Normal University (Philosophy and Social Science), 2012 (02). 